\title{
Serum enzymes markers in myocardial infarction: A study of rural area
}

\author{
Mamata Pochhi', M G Muddeshwar ${ }^{2}$ \\ ${ }^{1}$ Associate Professor, Department of Biochemistry, Shree Shankaracharya Institute of Medical Science, Bhilai, \\ Chhattisgarh, ${ }^{2}$ Professor and Head, Department of Biochemistry, Government Medical College, Nagpur, \\ Maharashtra, India
}

Background: Acute Myocardial Infarction is the reduction of coronary flow to such an extent that supply of oxygen to the myocardium do not need the oxygen demand of myocardial tissues. The diagnosis of AMI cannot be fulfilled unless the elevated levels of serum cardiac enzymes particularly CK-MB iso-enzyme activity. The rate of release of cardiac enzymes is highly diagnostic. Aims and Objectives: Therefore, the present thesis aim is-in evaluating, whether the elevated levels of cardiac marker enzymes can be compared to the extent of the Myocardial infarction. Material and Methods: Therefore the present study was undertaken on 50 patients of $\mathrm{MI}$ and 50 patients of control. They were group according to the age and sex. The activity of different cardiac enzymes were studied. Result: The AMI patients had significantly elevated levels of $90 \%$ patients of high LDH values and $86 \%$ patients have elevated levels of AST. The significant elevation of serum enzymes as compared to the control. Conclusion: The magnitude of the elevated levels of enzymes can be compared to the extent of the myocardial infarction. Serum GGT can also be useful marker of oxidative stress in myocardial infarction.

Key words: Myocardial infarction, CK-MB, LDH, GGT, SGOT

\section{INTRODUCTION}

Myocardial Infarction is one of the most common manifestation of cardiovascular disease. The morbidity and mortality of Myocardial Infarction is now a days reaching epidemic proportion throughout the world. Acute myocardial infarction (AMI) is the leading cause of death in developed countries. ${ }^{1}$ However, mortality from this cause has been declining over the last three decades because of early diagnosis and proper treatment. ${ }^{2}$

The diagnosis of AMI was based on the criteria set by the World Health Organization (WHO) and had to include two of the following: 1) typical history of prolonged ischaemic chest pain; 2) presence of typical acute ischaemic changes in the electrocardiograms (ECG);3) typical rise and fall of cardiac enzymes in blood like CK-MB, LDH, AST. ${ }^{3}$
The sensitivity and specificity of these markers have been enhanced by development of the iso-enzyme analysis. The CK-MB iso-enzyme activity appears to be the most sensitive and single specific serum enzyme level which can be helped to detect myocardial injury. ${ }^{4}$ The second enzyme GGT (Gamma Glutamyl Transferase) activity normally found in the serum as well as in the plasma membrane, virtually in all cell catalyzes the first step in degradation of extra cellular Glutathione and allowing for precursor amino acid to be assimilated and reutilized for intra GSH synthesis. ${ }^{5}$ More recently elevated serum GGT has also been found to correlate with cardiovascular diseases and is under active investigation as a cardiovascular risk marker. GGT in fact accumulates in atherosclerotic plaques, suggesting a potential role in pathogenesis of cardiovascular diseases. ${ }^{6,7}$

Therefore this enzyme study was undertaken to evaluate the role of various enzymes in patients with myocardial infarction and the ischemic heart disease. 


\section{MATERIALS AND METHODS}

The present study was conduced in the Department of Biochemistry, Government Medical College \& Hospital, Nagpur, during July 2009 to August 2010 with proper ethical approval and patient consent. The present study was performed on 50 patients of myocardial infarction from nearer areas of college and 50 age/sex matched controls. They were grouped according to the age i.e., $\geq 50$ and $\leq 50$. After the detail history and clinical examination of all individual who had diagnosed as myocardial infarction patients were taken for biochemical analysis.

For the control study healthy 50 volunteers were selected and match with the age and sex with the study group, there were 32 males and 18 females in the controlled group and 35 males and 15 females in myocardial infarction patients (different numbers in groups depends on availability). The average age of the control was $53.72 \pm 9.8$ years and for myocardial infarction $59.20 \pm$ 2.57 years. (Table 1 )

Samples were collected with 20 to 40 hours after the onset of chest pain. All the enzyme assay were carried out in serum sample for the study group and normal group within 24 hours.

\section{Analytical methods}

AST, LDH and CK-MB activity were determined by enzymatic method and GGT by colorimetric end point method. ${ }^{7-10}$

\section{RESULTS}

In present study all the levels of serum enzymes observed significant elevation. All the enzymes particularly CK-MB was significantly increased four folds than its normal. In the study, out of 50 patients with AMI 48 (96\%) shows elevated levels of CK-MB and 2 patients had CK-MB value within normal range. AST value had elevated in 43 patients $(86 \%)$ while $7(14 \%)$ patients had AST value within normal. 45 patients $(90 \%)$ had highly elevated LDH activity and $5(10 \%)$ patients shows normal LDH activity. These observations of our study are comparable to the study reported by the others.

Table 2 shows that all four serum enzymes AST, LDH, $\mathrm{CK}-\mathrm{MB}$ and GGT were significantly $(\mathrm{P}<0.001)$ elevated in AMI subjects than in control group.

Table 3 shows a significant increased value of AST, LDH, CKMB \& GGT in $\leq 50$ years of group of AMI patients when compared with control of same age.
Table 4 shows that there was statistically significant increased values of AST, LDH, CKMB and GGT $\geq 50$ age of AMI patients when compared with healthy control of same age group.

The AMI patients had significantly $96 \%$ elevated levels of CK-MB, $90 \%$ patients of high LDH values and $86 \%$ patients have elevated level of AST, the significant elevation of serum enzymes as compared with controlled group as shown in Table 5. The magnitude of the elevated levels of serum enzymes can be compared to the extent of

\begin{tabular}{|c|c|c|}
\hline & Control & AMI \\
\hline Total no. of cases & 50 & 50 \\
\hline Male & 32 (64\%) & $35(70 \%)$ \\
\hline Female & $18(36 \%)$ & $15(30 \%)$ \\
\hline Age (yrs) & $53.72 \pm 9.38$ & $59.20 \pm 12.57$ \\
\hline
\end{tabular}

\begin{tabular}{lcccc}
\multicolumn{4}{l}{ Table 2: Serum enzymes levels in AMI \& control } \\
\hline Subjects & AST & LDH & CKMB & GGT \\
\hline Control $(n=50)$ & $23.94 \pm 5.90$ & $409 \pm 112.22$ & $13.66 \pm 4.12$ & $20 \pm 7.93$ \\
AMI $(n=50)$ & $55.12 \pm 16.54$ & $925 \pm 164.75$ & $80.3 \pm 44.26$ & $55.32 \pm 11.26$ \\
\hline
\end{tabular}

Mean \pm S.D. is given, $P<0.001$ when compared with control group, Values expressed in IU/L

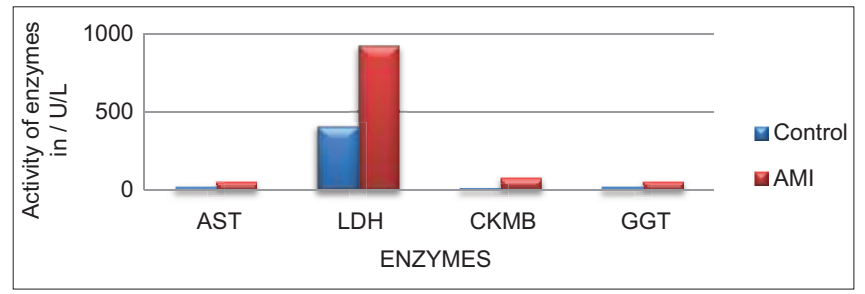

Table 3: Change in serum enzyme levels in AMI \& control $\leq 50$ yrs age group

\begin{tabular}{lcccc}
\hline Subject & AST & LDH & CKMB & GGT \\
\hline Control $(n=12)$ & $24.39 \pm 5.68$ & $413 \pm 111.87$ & $14.02 \pm 3.82$ & $21.23 \pm 8.88$ \\
AMI $(n=09)$ & $51.33 \pm 17.19$ & $863 \pm 108.21$ & $62.48 \pm 27.26$ & $46.66 \pm 7.51$ \\
\hline Mean \pm S.D. is given, & $P<0.001$ when compared with control group, Expressed in IU/L
\end{tabular}

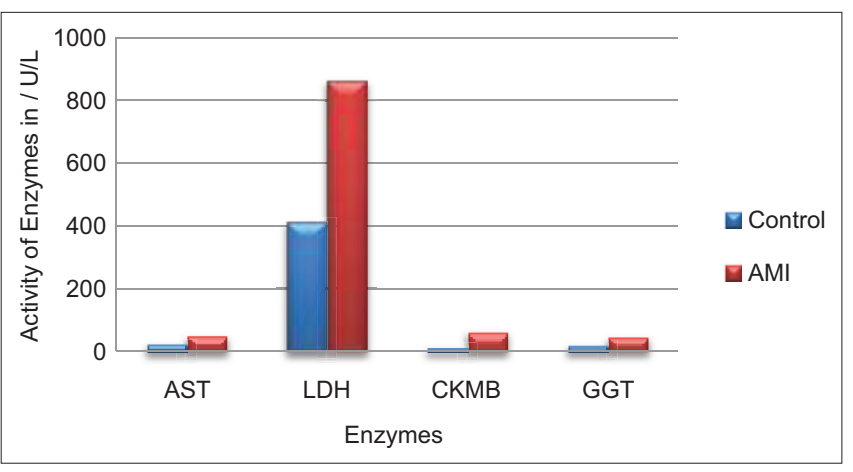




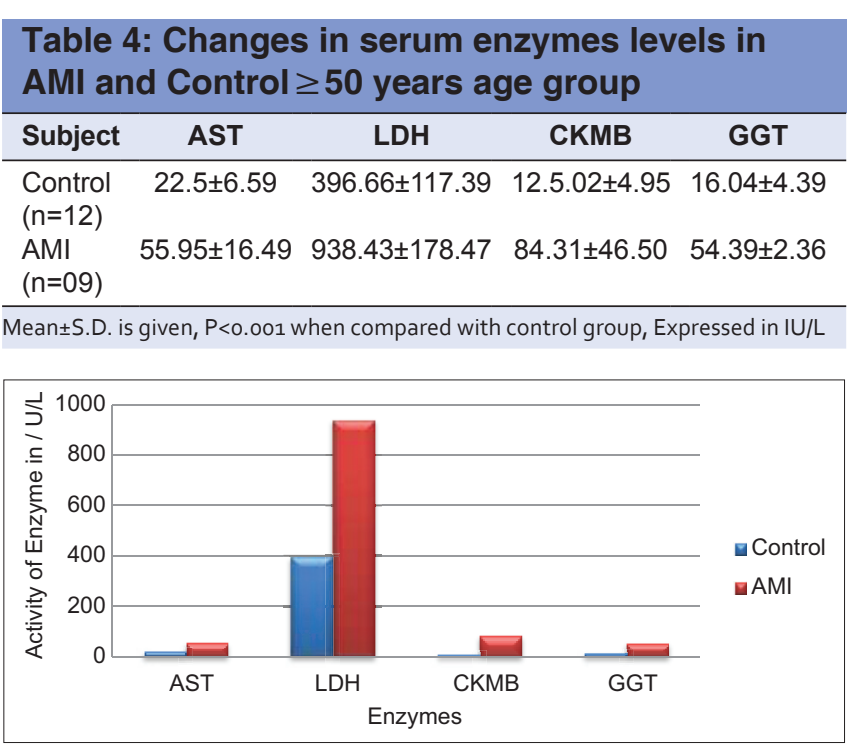

\begin{tabular}{|c|c|c|c|c|}
\hline & AST & LDH & CKMB & GGT \\
\hline $\begin{array}{l}\text { Normal } \\
\text { range }\end{array}$ & $42-28.91 \mathrm{IU} / \mathrm{L}$ & $200-650 \mathrm{IU} / \mathrm{L}$ & $0-25 \mathrm{IU} / \mathrm{L}$ & $0-45 \mathrm{IU} / \mathrm{L}$ \\
\hline $\begin{array}{l}\text { No. of } \\
\text { patients }\end{array}$ & 43 & 45 & 48 & 36 \\
\hline Percentage & $86 \%$ & $90 \%$ & $96 \%$ & $72 \%$ \\
\hline
\end{tabular}

$96 \%$ patients of $A M I$ had high value of CKMB, $90 \%$ patients had elevated value of $\mathrm{LDH}, 86 \%$ patients had elevated value of AST than normal range, $72 \%$ patients had higher value of GGT than normal range

the myocardial infarction. GGT can also be useful marker of oxidative stress in myocardial infarction.

All four serum enzymes AST, LDH, CK-MB and GGT were significantly $(\mathrm{P}<0.001)$ elevated in AMI subjects than in control group.

There was a significant increased value of AST, LDH, CKMB \& GGT in $\leq 50$ years of group of AMI patients when compared with control of same age.

Table 4 shows that there was statistically significant increased values of AST, LDH, CKMB and GGT $\geq 50$ age of AMI patients when compared with healthy control of same age group.

\section{DISCUSSION}

The diagnosis of AMI based upon the clinical symptoms, ECG changes and characteristics changes in enzyme. Since the clinical symptoms are not very reliable. ECG is most widely used method for the diagnosis of AMI, but many times ECG shows inclusive pattern. In such situation the importance of serum biochemical markers of myocardial injury arises to confirm the diagnosis. ${ }^{11}$ The need for enzymes assay in the diagnosis of cardiac diseases, stress from the relative inaccuracy of current diagnostic method. Twenty-thirty percent of AMI are not diagnosed clinically. However the physician trust upon most often in the diagnosis of myocardial infarction on ECG. Though it may reveal the diagnosis to the number of situation.

The reliability of the panel of the cardiac enzymes is now considered good enough so that CHD and AMI may be excluded as a diagnostic consideration. If all the three enzymes levels particularly AST, LDH and CK-MB are consistently normal. Elevation of cardiac enzymes are rarely if ever seen. It is believed that myocardial necrosis has indeed occurred. Increased serum enzyme activity associated with the AMI generally results from release of enzyme from myocardial itself. Several factors may influence the rate of depletion of enzymes from myocardium and appears in serum including the balance between myocardial oxygen supply and demand. ${ }^{12}$

The rate of appearance of enzyme in serum is not influenced by the myocardial enzymes depletion with release from the heart but also the contribution of enzymes release from non myocardial sources. ${ }^{13} \mathrm{CK}$ is released in skeleton muscles, hence the quantitative relation between serum CK depletion attack, which are responsible for many of the false positive enzymes elevation reported particularly in early studies, when iso-enzymes study were not available. ${ }^{14-16}$

Several studies have shown the elevated relation between peak serum enzyme activities after myocardial infarction. ${ }^{17-19}$

Lindsay et al. ${ }^{20}$ are argued that the metabolic effect that leads to increase in flux may fully and partially reversible, therefore the elevation of CK-MB could signify the adverse effect on the myocardial cell resulting from something other than necrosis or ischemia.

Thaygeshen et al. reported that the sensitivity of elevated serum LDH activity as a diagnostic criteria of AMI is some what les than that of the AST and CK-MB. Our study also showed that elevation of serum $\mathrm{LDH}$ was less as compared to high value observed in all patients. ${ }^{21}$

Lee D.H. et al. reported in their epidemiological studies that serum GGT within its normal range be an early and sensitive enzyme related to oxidative stress. An increase of GGT might be interpreted as defense mechanism reflecting induction of cellular GGT under oxidative stress. ${ }^{18}$

The present findings suggest that serum GGT may be increase due to increase oxidative stress in AMI. Thus 
serum GGT may be useful marker of oxidative stress in AMI and IHD.

\section{CONCLUSION}

Significant elevation of CK-MB activity as compared to AST and LDH proves as a single enzyme criteria for the early markers of AMI.

Serum GGT might be useful marker of oxidative stress in AMI.

The extent of myocardial infarction can be made by the magnitude of elevated serum enzyme levels.

\section{REFERENCES}

1. Sans $\mathrm{S}$, Kesteloot $\mathrm{H}$ and Kromhout D. The burden of cardiovascular disease mortality in Europe: Task Force of the European Society of Cardiology on Cardiovascular Mortality and Morbidity Statistics in Europe. Eur Heart J 1997; 18:1231-1248.

2. Ericsson CG, Lindvall $B$ and Olsson $G$. Trends in coronary care: A retrospective study of patients with myocardial infarction treated in coronary care units. Acta Med Scand 1988; 224:507-513.

3. World Health Organization. Nomenclature and criteria for diagnosis of ischemic heart disease: Report of the Joint International Society and Federation of Cardiology/World Health Organization task force on standardization of clinical nomenclature. Circulation 1979; 59(3):607-609.

4. Alpert JS and Thygesen K. Myocardial Infarction Redefined - A consensus document of the joint European Society of Cardiology/ American College of Cardiology Committee for the redefinition of Myocardial Infarction. Eur Heart J 2000; 21:1502-1513.

5. Apple ES. Acute myocardial infarction and Coronary reperfusion. Ann J Clin Path 1992; 97:217-226.

6. Wu AHB. Introduction to coronary artery disease (CAD) and Biochemical Markers. Cardiac Markers Totowa, NJ: Human Press Inc 1998; 3-20.

7. Bergmeyer HU, Horder M and Rej R. IFCC method for aspartate aminotransferase. J Clin Chem Clin Biochem 1986; 24(7): 497-510.

8. Bergmeyer HU, Horder M and Rej R. IFCC Methods for the measurement of catalytic concentrations of enzymes. J Clin Chem Clin Biochem 1986; 24:481.

9. Reference procedures for the determination of creatine kinase activity. Clin Chem Clin Biochem 1977; 15:249-254.

10. Szewczuk A, Kuropatwa M and Lang D. Colorimetric method for assay of serum gamma-glutamyltransferase activity with some L-gamma-glutamyl-carboxyanilides. Clin Chim Acta 1988;178(1):35-40.

11. Perryman MB, Strauss AW, Buettner $T L$ and Roberts R. Molecular heterogeneity of creatine kinase isoenzymes. Biochim Biophys Acta 1983;747(3):284-290.

12. Whitefield JB. Gamma Glutamyl Transferase. Crit Rev Clin Lab Sci 2001; 38(4):263-355.

13. West M, Gelb D and Pilz CG. Serum enzymes in disease VII: Significance of abnormal serum enzyme levels in cardiac failure. Am J Med Sci 1961; 241:350-358.

14. Sobel BE and Shell WE. Serum enzymes determination in the diagnosis and assessment of myocardial infarction. Circulation 1972; 45:471.

15. Coodley EL. Elevation of serum enzyme diagnosis in myocardial infarction. Amm Med Sci 1968; 256:300-305.

16. Shell WE, Lavelle JF, Covell JW and Sobel BE. Early Estimation of Myocardial Damage in Conscious Dogs and Patients with Evolving Acute Myocardial Infarction. J Clin Invest 1973; 52:2579-2590.

17. Emdin M, Passion C, Pompella A and Paolicchi A. Gamma Glutamyl transferase as cardiovascular risk factor. European Heart Journal 2006; 27:2145-2146.

18. Duk Hee Lee, Gang Hu, Kam and Silventionnin. Serum gamaglutamyl transferase predicts non-fatal myocardial infarction and fatal coronary heart disease among 28838 middle aged men and women. European Heart Journal 2006; 27:2170-2176.

19. Kay AD. Plasma phosphate on ostiosis deforms and other disease of bone. British J Exp Path 1929; 10(4):253-256.

20. White RD, Grande P, Califf L, Palmeri ST, Califf RM and Wagner GS. Diagnostic and prognostic significance of minimally elevated creatine kinase-MB in suspected acute myocardial infarction. Am J Cardiol 1985; 55(13 Pt 1):1478-1484.

21. Nigam PN. Biochemical markers of myocardial injury. Indian $\mathrm{J}$ Clin Biochem 2007; 22(1): 10-17.

\section{Authors Contribution:}

MP - Concept and design of the study, collected data, literature search, statistically analyzed and interpreted, prepared first draft of manuscript; MGM - Review of study, review of literature, critical revision of the manuscript.

Source of Support: Nil, Conflict of Interest: None declared. 